\title{
PHYSICAL-HYDRAULIC PROPERTIES OF A SANDY LOAM TYPIC PALEUDALF SOIL UNDER ORGANIC CULTIVATION OF 'MONTENEGRINA' MANDARIN (Citrus deliciosa TENORE) ${ }^{(1)}$
}

\author{
Caroline Valverde dos $\operatorname{Santos}^{(2)}$, Renato Levien ${ }^{(3)}$, Sérgio Francisco Schwarz ${ }^{(4)}$, Michael \\ Mazurana $^{(2)}$, Henrique Belmonte Petry ${ }^{(5)}$, Lucas Zulpo ${ }^{(6)}$ \& Jefferson Antônio Fink $^{(7)}$
}

\section{SUMMARY}

Citrus plants are the most important fruit species in the world, with emphasis to oranges, mandarins and lemons. In Rio Grande do Sul, Brazil, most fruit production is found on small properties under organic cultivation. Soil compaction is one of the factors limiting production and due to the fixed row placement of this crop, compaction can arise in various manners in the interrows of the orchard. The aim of this study was to evaluate soil physical properties and water infiltration capacity in response to interrow management in an orchard of mandarin (Citrus deliciosa Tenore 'Montenegrina') under organic cultivation. Interrow management was performed through harrowing, logs in "V", mowing, and cutting/knocking down plants with a knife roller. Soil physical properties were evaluated in the wheel tracks of the tractor (WT), between the wheel tracks (BWT), and in the area under the line projection of the canopy (CLP), with undisturbed soil samples collected in the $0.00-0.15,0.15-0.30,0.30-0.45$, and $0.45-0.60 \mathrm{~m}$ layers, with four replicates. The soil water infiltration test was performed using the concentric cylinder method, with a maximum time of $\mathbf{9 0}$ min for each test. In general, soil analysis showed a variation in the physical-hydraulic properties of the Argissolo Vermelho-Amarelo distrófico arênico (sandy loam Typic Paleudalf) in the three sampling sites in all layers, regardless of the management procedure in the interrows. Machinery traffic leads to heterogeneity in the soil physical-hydraulic properties in the interrows of

\footnotetext{
(1) Part of the Master's thesis of the first author, presented to the Soil Science Department of the Universidade Federal de Rio Grande do Sul - UFRGS. Received for publication on February 7, 2014 and approved on July 23, 2014.

(2) Doctoral student in Soil Science, UFRGS. Av. Bento Gonçalves, 7712. CEP 91540-000 Porto Alegre (RS), Brazil. E-mail: cvalsan2012@gmail.com, michael.mazurana@gmail.com

(3) Associate Professor, Soil Science Department, UFRGS. E-mail: renatole@ufrgs.br

(4) Adjunct Professor, Horticulture and Forestry Department, UFRGS. E-mail: schwarz@ufrgs.br

(5) Researcher at Epagri - Empresa de Pesquisa Agropecuária e Extensão Rural de Santa Catarina. Experimental Station of Urussanga. SC 108 Road, km 353. CEP 88840-000 Urussanga (SC), Brazil. E-mail: henriquepetry@epagri.sc.gov.b

(6) Master student in Soil Science, UFRGS. E-mail: lucaszulpo@yahoo.com.br

(7) Undergraduate student in Agricultural Mechanization, UFRGS. E-mail: jeffe.fink@hotmail.com
} 
the orchard. Soil porosity and bulk density are affected especially in the wheel tracks of the tractor (WT), which causes a reduction in the constant rate of infiltration and in the accumulated infiltration of water in this sampling site. The use of the disk harrow and mower leads to greater harmful effects on the soil, which can interfere with mandarin production.

Index terms: citrus production, farm equipment, organic growing.

\title{
RESUMO: ATRIBUTOS FÍSICO-HÍDRICOS DE UM ARGISSOLO VERMELHO- AMARELO DISTRÓFICO ARÊNICO SOB CULTIVO ORGÂNICO DE TANGERINEIRAS MONTENEGRINA
}

\begin{abstract}
As plantas cítricas são as espécies frutíferas de maior importância mundial, com destaque para as laranjeiras, tangerineiras e limoeiros. No Rio Grande do Sul, a maior parte da produção do fruto é realizada em pequenas propriedades, sob produção orgânica. A compactação do solo é um dos fatores limitantes na produção que, em razão do espaçamento fixo da planta, pode apresenta-se de forma variada nas entrelinhas do pomar. Este estudo teve por objetivo avaliar os atributos físicos e a capacidade de infiltração de água no solo, em resposta ao manejo das entrelinhas de um pomar de tangerinas (Citrus deliciosa Tenore) cv. 'Montenegrina' sob cultivo orgânico. Os manejos foram realizados por meio de gradagem, arraste de tronco em "V", roçada e acamamento com rolo-faca. Os atributos físicos do solo foram avaliados na linha de tráfego do rodado do trator (R), na entrelinha de tráfego dos rodados do trator (ER) e sob a linha de projeção da copa (LPC), com amostras indeformadas coletadas nas camadas de 0,00-0,15; 0,15-0,30; 0,30-0,45; e 0,45-0,60 m e quatro repetições. A infiltração de água no solo foi realizada com cilindros duplos concêntricos, com tempo máximo de 90 min para cada ensaio. A análise do solo apresentou, de modo geral, variação nos atributos físico-hídricos do Argissolo Vermelho-Amarelo distrófico arênico, nos três locais de amostragem, em todas as profundidades e independentemente do manejo realizado nas entrelinhas do pomar de tangerineiras. O tráfego de máquinas promoveu heterogeneidade nos atributos físico-hídricos das entrelinhas do pomar. A porosidade e a densidade do solo foram influenciadas principalmente na linha de tráfego dos rodados do trator (R), que gerou redução na taxa constante de infiltração e na infiltração acumulada de água nesse local de amostragem. O uso de grade de disco e o de roçadeira promoveram maiores efeitos deletérios no solo, o que pode interferir na produção das tangerineiras.
\end{abstract}

Termos de indexação: citricultura, máquinas agrícolas, cultivo orgânico.

\section{INTRODUCTION}

Citrus crops are the most important fruit species in the world, with emphasis to oranges, mandarins and lemons. Rio Grande do Sul, Brazil, is the third largest producer in the national ranking (FAO, 2009), with the Caí Valley as its largest production region, where the 'Montenegrina' variety prevails (Montenegro, 2013).

Citrus production in the Caí Valley is concentrated on small properties, under organic and biodynamic growing. The latter, although based on the same principles and techniques of organic agriculture, has some particular features, such as spiritual issues related to anthroposophy, the use of biodynamic preparations. and astrological calendars (IBD, 2009).

The activities performed in citrus orchards in Rio Grande do Sul involve weed control, fertilization, pruning, fruit thinning, plant health measures, and harvest. Most of them are performed with the aid of farm equipment and some orchards are subject to as many as 300 passes of this equipment between plant rows throughout their existence.

Richart et al. (2005) claim that farm equipment traffic is considered to be the main cause of soil compaction between plant rows in Brazilian orchards. According to Servadio et al. (2005), deliberate use of machines in citrus orchards leads to reduction in macropore volume (pores $>0.05 \mu \mathrm{m}$ ), whereas micropore volume (pores $<0.05 \mu \mathrm{m}$ ) remains unchanged, affecting total soil porosity. Li et al. (2007) claim that this change in soil porosity reduces water infiltration capacity and soil water storage. In this context, an understanding of water infiltration capacity and its relation to soil physical properties is essential for efficient soil and water management in agricultural production (Reichardt \& Timm, 2004).

Since mandarin is a perennial crop with fixed spacing between plant rows, the tractor tracks in these orchards are always in the same position. That 
causes a soil-tire contact "exclusive zone", creating heterogeneity in the soil physical-hydraulic properties in the interrows of the orchards. Soil samplings were performed in the wheel tracks and between the wheel tracks in order to identify possible physical-hydraulic restrictions to development of citrus crops in Brazilian orchards (Fidalski et al., 2007).

Based on the above, the aim of this study was to evaluate soil physical-hydraulic properties in response to interrow management in a 'Montenegrina' mandarin orchard under organic growing. The hypothesis is that the interrow management in citrus orchards leads to heterogeneity in soil compaction in areas under the wheel tracks of the machinery and outside the area of these tracks, impairing soil water dynamics.

\section{MATERIAL AND METHODS}

The experiment was carried out in an organic orchard of mandarin (Citrus deliciosa Tenore 'Montenegrina'), located in the physiographic region of the Depressão Central of Rio Grande do Sul, Brazil. The climate of the area is Cfa - humid subtropical, with average temperature near $25^{\circ} \mathrm{C}$, average annual rainfall of 1,440 mm (Bergamaschi et al., 2003), and slope from 0.08 to $0.12 \mathrm{~m} \mathrm{~m}^{-1}$.

The soil of the area was classified as sandy loam Typic Paleudalf, according to Soil Survey Staff (2010), with $0.86,0.83,0.84$, and $0.78 \mathrm{~kg} \mathrm{dm}^{-3}$ of sand in the $0.00-0.15,0.15-0.30,0.30-0.45$, and $0.45-0.60 \mathrm{~m}$ soil layers, respectively, according to the results obtained through the pipette method (Embrapa, 2011), There was predominance of medium and fine sand fractions, and particle density ranging from 2.54 to $2.55 \mathrm{~kg} \mathrm{dm}^{-3}$ (Table 1), determined using the volumetric flask method (Embrapa, 2011). This is within the proper limits for sandy soils (2.30 to $2.90 \mathrm{~kg} \mathrm{dm}^{-3}$ ), according to Libardi (2005).

The orchard was planted in 1990 in a conventional management system, with seedlings placed at $3.0 \mathrm{~m}$ between plants and $6.5 \mathrm{~m}$ between rows in $234 \mathrm{~m}^{2}$ plots, consisting of three rows of five plants each for a total of 15 plants per plot. The three central rows were considered as the useful plot area and a border row separated the treatments.

The area was converted to an organic system in 1998, and then to a biodynamic system in 2009 . Fertilizations were performed in biannual intervals, with the application of $30 \mathrm{~m}^{3} \mathrm{ha}^{-1}$ of solid compound and $30 \mathrm{~m}^{3} \mathrm{ha}^{-1}$ of liquid biofertilizers prepared using citrus bagasse and the bark of acacia (Acacia mearnsii), provided by the cooperative Ecocitrus, bringing about soil organic matter $(\mathrm{OM})$ content of 50 and $20 \%$ in the $0.00-0.15$ and $0.15-0.30 \mathrm{~m}$ surface layers, respectively (Table 1), according to the Walkley-Black method (Tedesco et al., 1995).

In the orchard interrows, there is rather diverse plant cover, with predominance of the species Synedrellopsis grisebachii Hieron, Acanthospermum hispidum DC, Ipoema cairica (L.) Sweet, Brachiaria plantaginea (Link), Cyperus rotundus L., and Lollium multiflorum Lam.

The treatments for weed control between plant rows were: T1 - Harrow: partial incorporation of spontaneous vegetation into the soil at approximately $0.10-0.15 \mathrm{~m}$ using a leveling harrow together with 201 .7-m-wide disks, in September, December, and March and weeding or mowing under the citrus canopy; T2 - Logs in "V": knocking down spontaneous vegetation at the end of its cycle or when taller than $60 \mathrm{~cm}$ by dragging two log segments arranged in a "V" shape, each of 30 to $40 \mathrm{~cm}$ diameter, using a device for attachment to the three-point hitch of the tractor; T3 - Mower: mechanical cutting of spontaneous vegetation using a 2.15-m-long, 1.7-m-wide mower pulled by a tractor when vegetation was taller than $60 \mathrm{~cm}$, and manual mowing in the interrows (September, December, and March); and T4 - Knife roller: knocking down spontaneous vegetation in the interrows using a $2-\mathrm{m}$ wide knife roller pulled by a tractor when vegetation was taller than $60 \mathrm{~cm}$, and manual mowing in the area under the citrus canopy.

Each plot was managed with one tractor pass in the interrows. Implements were pulled by a Yanmar 1055 tractor (55HP/2WD), weighing $1,985 \mathrm{~kg}$. Sets of

Table 1. Particle-size distribution, particle density (PD) and organic matter content (OM) in the Sandy Loam Typic Paleudalf

\begin{tabular}{|c|c|c|c|c|c|c|c|c|c|c|}
\hline Layer & VCS & CS & MS & FS & VFS & Total sand & Silt & Clay & PD & $\mathrm{OM}$ \\
\hline $\mathrm{m}$ & & & . & $-\mathrm{k}$ & -1 & & & & $\mathrm{~kg} \mathrm{dm^{-3 }}$ & $\%$ \\
\hline $0.00-0.15$ & 0.00 & 0.07 & 0.42 & 0.31 & 0.07 & 0.86 & 0.08 & 0.05 & 2.55 & 50.00 \\
\hline $0.15-0.30$ & 0.00 & 0.06 & 0.40 & 0.30 & 0.07 & 0.83 & 0.07 & 0.10 & 2.54 & 20.00 \\
\hline $0.30-0.45$ & 0.00 & 0.07 & 0.41 & 0.30 & 0.06 & 0.84 & 0.07 & 0.10 & 2.54 & 9.00 \\
\hline $0.45-0.60$ & 0.00 & 0.05 & 0.37 & 0.29 & 0.07 & 0.78 & 0.06 & 0.16 & 2.54 & 1.00 \\
\hline
\end{tabular}

Particle size classification by the USDA: VCS (very coarse sand) = particles between 2.0 and $1.0 \mathrm{~mm}$; CS (coarse sand) = particles between 1.0 and $0.5 \mathrm{~mm}$; MS (medium sand) = particles between 0.5 and $0.25 \mathrm{~mm}$; FS (fine sand) = particles between 0.25 and $0.105 \mathrm{~mm}$; VFS (very fine sand) = particles between 0.105 and $0.053 \mathrm{~mm}$; total sand $=2.0-0.053 \mathrm{~mm}$; silt $=0.05-0.002 \mathrm{~mm}$; clay $<0.002 \mathrm{~mm}$. 
18.4-30R1 and 14.9-24R1 diagonal tires were used on the tractor for rear and front axles, respectively.

Analyses of the soil physical-hydraulic properties were performed from July 2012 to February 2013. Evaluations were performed in soil samples collected at three different sites in the interrows: $B W T$ (between the wheel tracks), $W T$ (in the wheel tracks) and $C P L$ (under the projection of the canopy), with four replicates per treatment (T1, T2, T3, and T4). Soil bulk density $(B D)$ was determined through the volumetric ring method (Embrapa, 2011), with undisturbed soil samples collected in the 0.00-0.15, 0.15-0.30, 0.30-0.45, and 0.45-0.60 m layers, using sharp-edged volumetric rings with a height of $5.0 \mathrm{~cm}$, diameter of $8.5 \mathrm{~cm}$, and volume of $283 \mathrm{~cm}^{3}$.

The same sample was used to determine macroporosity $(M a)$, through the tension-table method, with a 60.0-cm water column to remove water from the samples through suction until they stopped draining (approximately $48 \mathrm{~h}$ ); microporosity (Mi), when samples were weighed again after the tension table, remaining in an oven at $105^{\circ} \mathrm{C}$ until constant weight, i.e., $48 \mathrm{~h}$ after the beginning of drying; and total soil porosity (TP), which was obtained by the sum of soil macro- and microporosity, according to Embrapa (2011).

Statistical analyses for soil density, macroporosity, microporosity, and total porosity were performed according to the split-plot design, using the software Statistical Analysis System (SAS), through analysis of variance. Whenever the $\mathrm{F}$ value was significant, the mean values of the treatments were compared using the Tukey test $(\mathrm{p}<0.05)$.

The water infiltration rate $(f)$ and accumulated infiltration $(I)$ were determined using double ring infiltrometers, both $40 \mathrm{~cm}$ in height and 30 and $50 \mathrm{~cm}$ of inner and outer diameters, respectively, according to the method described by Bernardo et al. (2006). Plant cover and surface roots were removed before placing the cylinders in order to avoid the interference of soil cover in water infiltration. This task was carefully performed using a hoe to avoid changes in the soil surface.

During the tests, hydraulic load was kept at approximately $15 \mathrm{~cm}$ height inside the inner ring. Whenever there was a decrease of $5.0 \mathrm{~cm}$ in the hydraulic load, the ring was manually replenished, and the adjusted height recorded. The maximum time for each test was $90 \mathrm{~min}$ and the results were expressed according to the average values of infiltration rate and accumulated infiltration obtained in each replicate.

\section{RESULTS AND DISCUSSION}

In general, soil physical analyses showed a variation in the physical-hydraulic properties of the sandy loam Typic Paleudalf for the three sampling sites in all layers, regardless of the interrow management applied in the mandarin orchard.

The $M a$ values in the 0.00-0.15 m layer (Table 2) were low, especially in the $W T$ of the interrows managed with log segments in " $\mathrm{V}$ " and the mower (0.06 and $0.10 \mathrm{~m}^{3} \mathrm{~m}^{-3}$, respectively). These results are close to the limiting value for aeration and root development which, according to Carter (2002), is 0.10 $\mathrm{m}^{3} \mathrm{~m}^{-3}$. However, there are crops that require an aeration volume either higher or lower than this critical limit (Reinert et al., 2001).

These values, even with high OM content (Table 1), are probably related to the fact that the surface experiences greater interference from soil management. In addition, the low $M a$ values in interrows managed with the dragging of log segments in "V" and the mower may be related to the absence of soil turn-over when these implements are used, which occurs even briefly in turned soils, such as in interrows managed with a harrow and knife roller.

However, the use of soil-turning and cutting implements (such as the harrow) in citrus orchards is controversial since, while turning the soil, the disks produce dust, cut roots, and, depending on the site, cause erosion (Durigan \& Timossi, 2002). Thus, they are no longer used in many regions.

Consequently, there was a variation in $M i$, in all sampling sites, regardless of the management used, with the highest values $\left(0.36 \mathrm{~m}^{3} \mathrm{~m}^{-3}\right)$ being observed in the WT (Table 2). Such reorganization of $M a$ and $M i$ in the soil caused a variation in $T P$; however, most of the observed results are found around the average value from 0.30 to $0.60 \mathrm{~m}^{3} \mathrm{~m}^{-3}$, mentioned by Hillel (1980) and Kiehl (1979) as the normal range verified for most mineral soils.

The highest BD values were found in the interrows managed with the harrow and mower, especially in the $W T$, reaching $1.54 \mathrm{~kg} \mathrm{dm}^{-3}$ in both treatments. Similar $B D$ values for harrow and mower treatments can be attributed to the fact that the cutting performed by the mower eliminates shoot apical dominance in plants, stimulating the growth of sprouts situated on the interface with the soil and, consequently, increasing the number of operations with these implements, which favors soil compaction; while the use of the harrow promotes cutting and turn-over in the surface soil layer, which also favors soil compaction (Alcântara et al., 2000).

The 0.15-0.30 m layer also showed low Ma values, regardless of the management used (Table 2). Sampling sites in $W T$ and $B W T$ showed values lower than and close to the limits for root development and soil aeration (from 0.08 to $0.11 \mathrm{~m}^{3} \mathrm{~m}^{-3}$ ).

The results found in this study are similar to those found by Reichardt \& Timm (2004) and Libardi (2005) for most Brazilian orchards (Ma values lower than 
$0.15 \mathrm{~m}^{3} \mathrm{~m}^{-3}$ ), which are ideal for citrus at the $0.30 \mathrm{~m}$ depth, according to these authors. In addition to the soil compaction effect, the values found in this study can also be attributed to the high contents of medium and fine sand, which, according to Souza (1996), contribute to pore obstruction, lower water infiltration, and higher possibility of erosion.

In general, in the three sampling sites, regardless of the management used, $M i$ values were considered as satisfactory for citrus (Table 2). According to Reichardt \& Timm (2004) and Libardi (2005), Mi values should be between 0.20 and $0.23 \mathrm{~m}^{3} \mathrm{~m}^{-3}$, without interfering in $T P$, which was between 0.30 and $0.35 \mathrm{~m}^{3} \mathrm{~m}^{-3}$ in this study, corroborating the ideal values for citrus in sandy soils in this same layer (Reichardt \& Timm, 2004; Libardi, 2005).

However, $B D$ was affected by soil management in the three sampling sites, with values ranging from 1.49 to $1.65 \mathrm{~kg} \mathrm{dm}^{-3}$. These values are considered higher than desirable for sandy soils, which, according to Durigan \& Timossi (2002), should be between 1.25 and $1.40 \mathrm{~kg} \mathrm{dm}^{-3}$. These same authors report that, due to compaction, most soils of Brazilian orchards show $B D$ values from 1.4 to $1.7 \mathrm{~kg} \mathrm{dm}^{-3}$ up to a depth of $0.30 \mathrm{~m}$.

The 0.30-0.45 $\mathrm{m}$ and 0.45-0.60 m layers had variations in the soil physical properties (Ma, Mi, TP,

Table 2. Bulk density $(B D)$, macroporosity $(M a)$, microporosity $(M i)$, and total porosity $(T P)$ in the 0.00-0.15, 0.15-0.30, 0.30-0.45, and 0.45-0.60 m layers, in the interrows under disk harrowing, knocking down weeds using logs in "V", mechanical mowing, and cutting/knocking down weeds using a knife roller for three sampling sites: under the projection of the canopy $(C P L)$, in the wheel tracks $(W T)$, and between the wheel tracks $(B W T)$

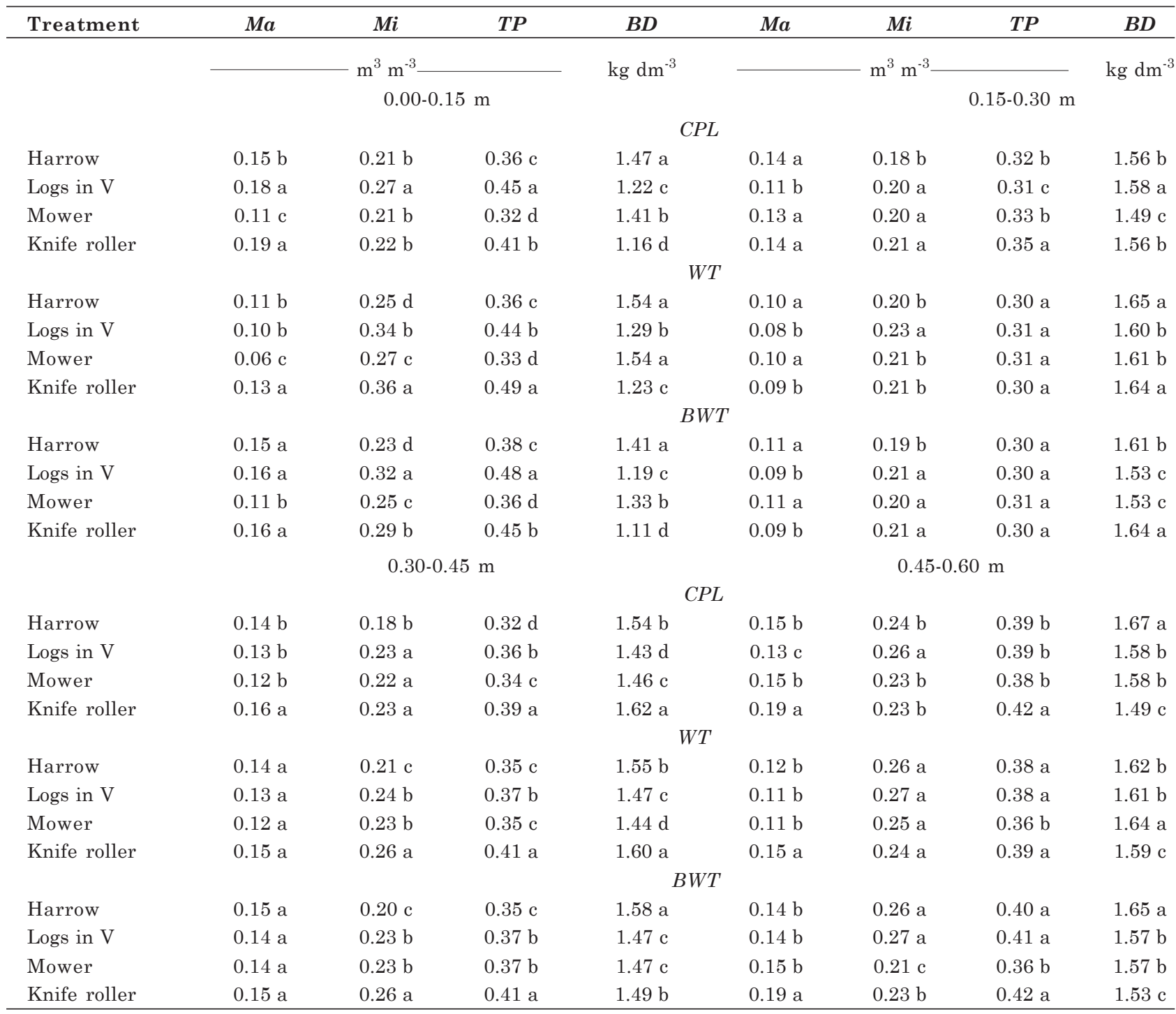

Means followed by the same letter in the columns do not differ by the Tukey test at $5 \%$ between treatments in the sampling sites. 
and $B D$ ), as shown in table 2 . However, this variation did not compromise soil macroporosity, which had values above the critical limit of $0.10 \mathrm{~m}^{3} \mathrm{~m}^{-3}$, regardless of the sampling site and implement used. This result can be attributed to the fact that interrow management and the tire-soil contact pressure do not affect soil structure in the deeper layers.

The water infiltration rate $(f)$ and the accumulated infiltration $(I)$ in the orchard interrows were affected by the compaction resulted from interrow management. The highest values were observed in the $C P L$, in all treatments (Figure 1).
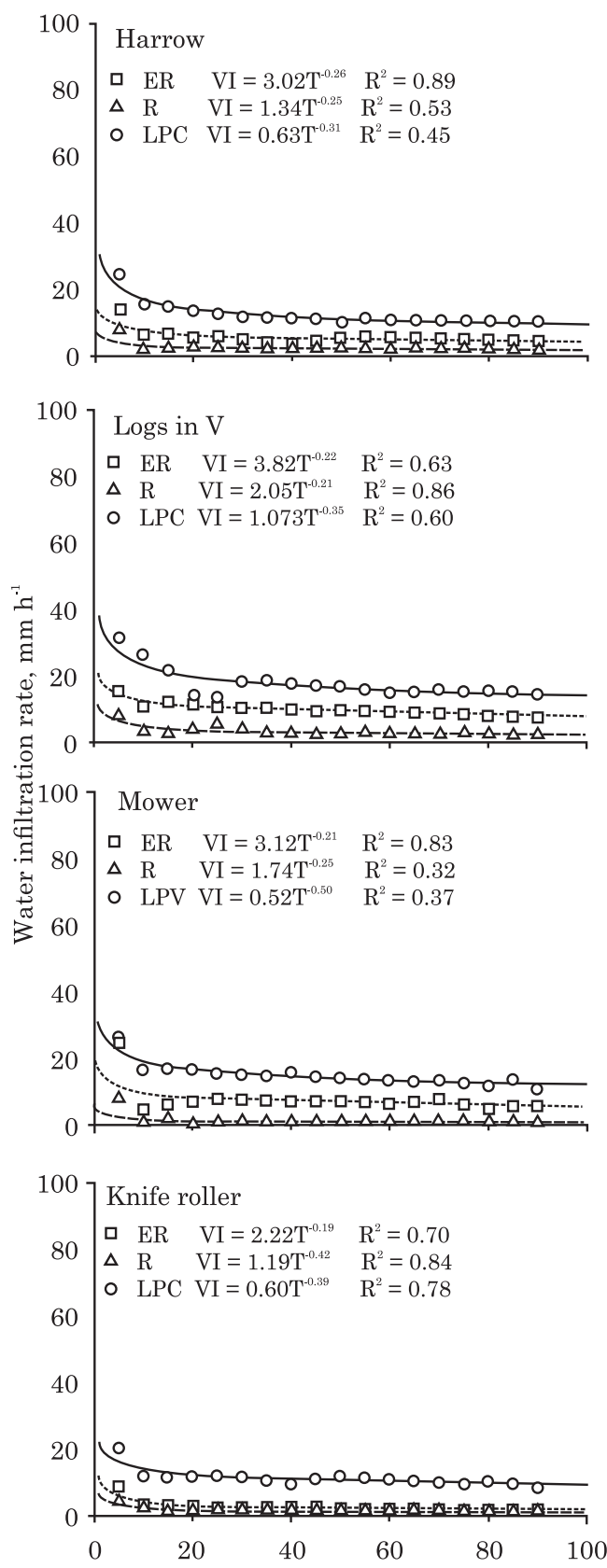

The intensity of machinery traffic, combined with soil particle-size distribution, with the predominance of medium and fine sands (Table 1), led to a low water infiltration rate $(f)$, especially in the $W T(f=2.99$, $3.83,2.98$, and $1.15 \mathrm{~mm} \mathrm{~h}^{-1}$ for harrow, log segments in "V", mower, and knife roller, respectively) and in $B W T\left(f=6.60,10.80,10.63\right.$, and $4.34 \mathrm{~mm} \mathrm{~h}^{-1}$ for harrow, log segments in "V", mower, and knife roller, respectively).

Texture variation throughout the profile (Bernardo et al., 2006) and the reduction in $M a$ lead to an increase in soil density and a decrease in the soil water
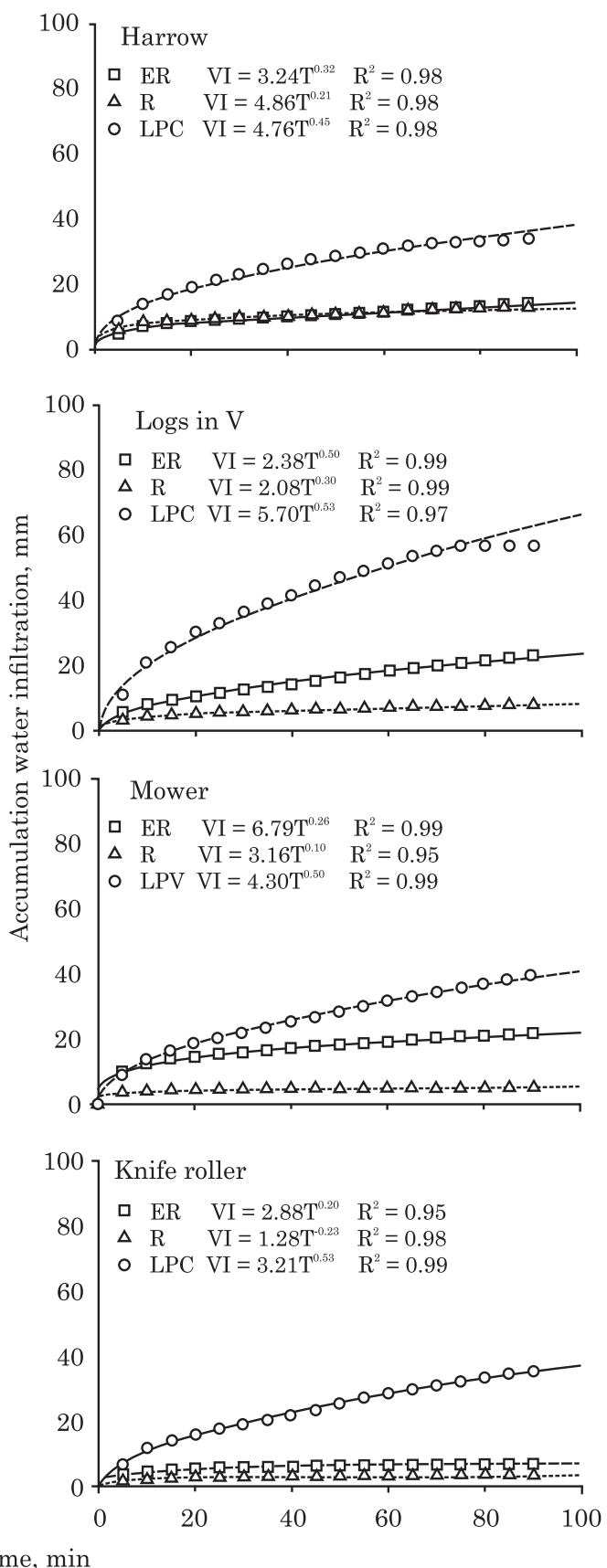

Figure 1. Water infiltration rate and accumulated water infiltration in three sampling sites: between the wheel tracks of the tractor (BWT), in the wheel tracks (WT), and under the projection of the canopy (CPL). 
infiltration rate (Panachuki et al., 2006), as observed in this study. Although the tensions exerted by the tractor wheels propagate mostly vertically in the soil, part of these tensions also propagate sideways, affecting the sites between the wheel tracks of the tractor (Trein, 1995).

Although the $C P L$ site had the highest $f$ values ( $f=13.9,20.55,15.52$, and $12.62 \mathrm{~mm} \mathrm{~h}^{-1}$ for harrow, log segments in "V", mower, and knife roller, respectively), they are considered low, since the ideal water infiltration rate for sandy soils should be between 25 and $250 \mathrm{~mm} \mathrm{~h}^{-1}$, according to Bernardo et al. (2006).

The highest $f$ values in this study were found in the interrow managed with the dragging of log segments in "V" $\left(f=20.55 \mathrm{~mm} \mathrm{~h}^{-1}\right)$. This result is contrary to that found by Pietrzacka (2009) in the same orchard, in which the highest $f$ values were found in the area under harrowing management, because the soil had been recently turned over in the interrows.

Water infiltration rates in all sampling sites had high initial values, which later decreased and reached a constant rate at $90 \mathrm{~min}$ of the test, as shown in the use of the Kostiakov equation. For Libardi (2005), although it is empiric, the Kostiakov equation is very useful for irrigation purposes due to its simplicity and because it is reasonably fitted to a great number of soils at short time intervals (up to $150 \mathrm{~min}$ ), in addition to providing information on the soil water absorption capacity.

Brandão et al. (2006) explain that, in general, when soil is turned over, the water infiltration capacity measured using double rings tends to increase because of the breakdown of soil structure in the surface layer, and it is higher in systems with soil management compared to others with less or no disturbance (Abrão et al., 1979). However, repeated soil management procedures can cause soil water infiltration rates lower than those in areas with no soil management.

In addition, after saturation, turned-over soils are more prone to surface erosion and transport of particles and nutrients, which is favored in a Sandy Loam Typic Paleudalf because of its great amount of sand particles. Therefore, it is necessary to maintain control over spontaneous vegetation in the interrows of the orchard for the purpose of avoiding soil losses by erosion and reduction in mandarin yield.

\section{CONCLUSIONS}

1. Machinery traffic leads to heterogeneity in soil physical-hydraulic properties in the interrows of the orchard.

2. Soil porosity and bulk density are especially affected in the tractor wheel tracks (WT), which causes a reduction in the constant infiltration rate and in the accumulated water infiltration in this sampling site.

3. The use of a disk harrow and mower leads to greater harmful effects on soil, which can interfere in mandarin production.

\section{LITERATURE CITED}

ABRÃO, P.U.R. Efeito de sistemas de preparo do solo sobre características de Latossolo Roxo distrófico. R. Bras. Ci. Solo, 3:169-172, 1979.

ALCÂNTARA, E.N. \& FERREIRA, M.M. Efeito de métodos de controle de plantas daninhas na cultura do cafeeiro (Coffea arabica L.) sobre a qualidade física do solo. R. Bras. Ci. Solo, 24:711-721, 2000.

BERNARDO, S.; SOARES, A.A. \& MANTOVANI, E.C. Manual de irrigação. 8.ed. Viçosa, MG, Universidade Federal de Viçosa, 2006. 625p.

BERGAMASCHI, H.; GUADAGNIN, M.R.; CARDOSO, L.S. \& SILVA, M.I.G. Clima da Estação Experimental da UFRGS (e região de abrangência). Porto Alegre, Universidade Federal do Rio Grande do Sul, 2003. 78p.

BRANDÃO, V.S.; CECILIO, R.A.; PRUSKI, F.F. \& SILVA, D.D. Infiltração da água no solo. 3.ed. Viçosa, MG, Universidade Federal de Viçosa, 2006. 120p.

CARTER, M.R. Quality, critical limits and standardization. In: LAL, R., ed. Encyclopedia of soil science. New York, Marcel Dekker, 2002. p.1062-1065.

DURIGAN, J.C. \& TIMOSSI, P.C. Manejo de plantas daninhas em pomares cítricos. Bebedouro, EECB, 2002. 53p.

EMPRESA BRASILEIRA DE PESQUISA AGROPECUÁRIA . EMBRAPA. Manual de métodos e análise de solo. 2.ed. Rio de Janeiro, CNPS, 2011. 230p.

FOOD AND AGRICULTURE ORGANIZATION OF THE UNITED NATIONS - FAO. Dados agrícolas de FAOSTAT: Crops. Cow peas, dry. 2009. Available at: $<\mathrm{http}: / / \mathrm{f}$ a o s t a t. fao.org/sit e/567/ DesktopDefault.aspx?PageID=567\#ancor $>$. Accessed on: Jan. 13, 2013.

FIDALSKI, J.; TORMENA, C.A. \& SILVA, A.P. Qualidade física do solo em pomar de laranjeira no noroeste do Paraná com manejo da cobertura permanente na entrelinha. R. Bras. Ci. Solo, 31:423-433, 2007.

HILLEL, D. Fundamentals of soil physics. New York, Academic Press, 1980. 413p.

INSTITUTO BIODINÂMICO - IBD. Diretrizes para o padrão de qualidade orgânico. Instituto Biodinâmico. 17.ed. Botucatu, 2009. 78p. (Documnto 812) Available at: <http:/ /www.ibd.com.br>. Accessed on: Jan. 10, 2013.

KIEHL, E.J. Manual de edafologia. São Paulo, Agronômica Ceres, 1979. 262p. 
LI, Y.X.; TULLBERG, J.N. \& FREEBAIRN, D.M. Wheel traffic and tillage effects on runoff and crop yield. Soil Till. Res., 97:282-292, 2007.

LIBARDI, P.L. Dinâmica da água no solo. São Paulo, Universidade de São Paulo, 2005. 335p.

MONTENEGRO. Prefeitura Municipal. [Informações sobre importância econômica]. Available at: <https:// www.montenegro.rs.gov.br/home/>. Accessed on: Jan. 13, 2013.

PANACHUKI, E.; SOBRINHO, T.A.; VITORINO, A.C.T.; CARVALHO, D.F. \& URCHEI, M.A. Parâmetros físicos do solo e erosão hídrica sob chuva simulada em área de integração agricultura-pecuária. R. Bras. Eng. Agríc. Amb., 10:261-268, 2006.

PIETRZACKA, R. Caracterização física e química de um Argissolo em área de citricultura orgânica com diferentes manejos da cobertura vegetal do solo. Porto Alegre, Universidade Federal do Rio Grande do Sul, 2009. 106p. (Dissertação de Mestrado)

RICHART, A.; TAVARES FILHO, J.; BRITO, O.R.; LLANILLO, R.F. \& FERREIRA, R. Compactação do solo: causas e efeitos. Ci. Agrár., 26:321-344, 2005.

REICHARDT, K. \& TIMM, L.C. Solo, planta e atmosfera: conceitos, processos e aplicações. São Paulo, Manole, 2004. 478 p.
REINERT, D.J.; REICHERT, J.M. \& SILVA, V.R. Propriedades físicas de solos em sistema de plantio direto irrigado. In: CARLESSO, R.; PETRY, M.T.; ROSA, G.M. \& CERETTA, C.A., eds. Irrigação por aspersão no Rio Grande do Sul. Santa Maria, Universidade Federal de Santa Maria, 2001. 165 .

SERVADIO, P.; MARSILI, A.; VIGNOZZI, N.; PELLEGRINI, S. \& PAGLIAI, M. Effects on some soil qualities in central Italy following the passage of four wheel drive tractor fitted with single and dual tires. Soil Till. Res., 84:87-100, 2005.

SOIL SURVEY STAFF. Keys to soil taxonomy. Washington, USDA, Natural Resources Conservation Service, 2010. $338 \mathrm{p}$.

SOUZA, L.S. Uso e manejo dos solos coesos dos Tabuleiros Costeiros. In: REUNIÃO TÉCNICA SOBRE SOLOS COESOS DOS TABULEIROS COSTEIROS, Cruz das Almas, 1996. Anais... Aracaju, Empresa Brasileira de Pesquisa Agropecuária, 1996. p.36-75.

TEDESCO, M.J.; GIANELLO, C.; BISSANI, C.A.; BOHNEN, H. \& VOLKWEISS, S.J. Análise de solo, plantas e outros materiais. Porto Alegre, Universidade Federal do Rio Grande do Sul, 1995. 174p. (Boletim Técnico, 5)

TREIN, C.R. The mechanics of soil compaction under wheels. Silsoe, Cranfield University, 1995. 132p. (Tese de Doutorado) 